\title{
House of Hits
}


BRAD AND MICHELE MOORE ROOTS MUSIC SERIES

UNIVERSITY OF TEXAS PRESS 


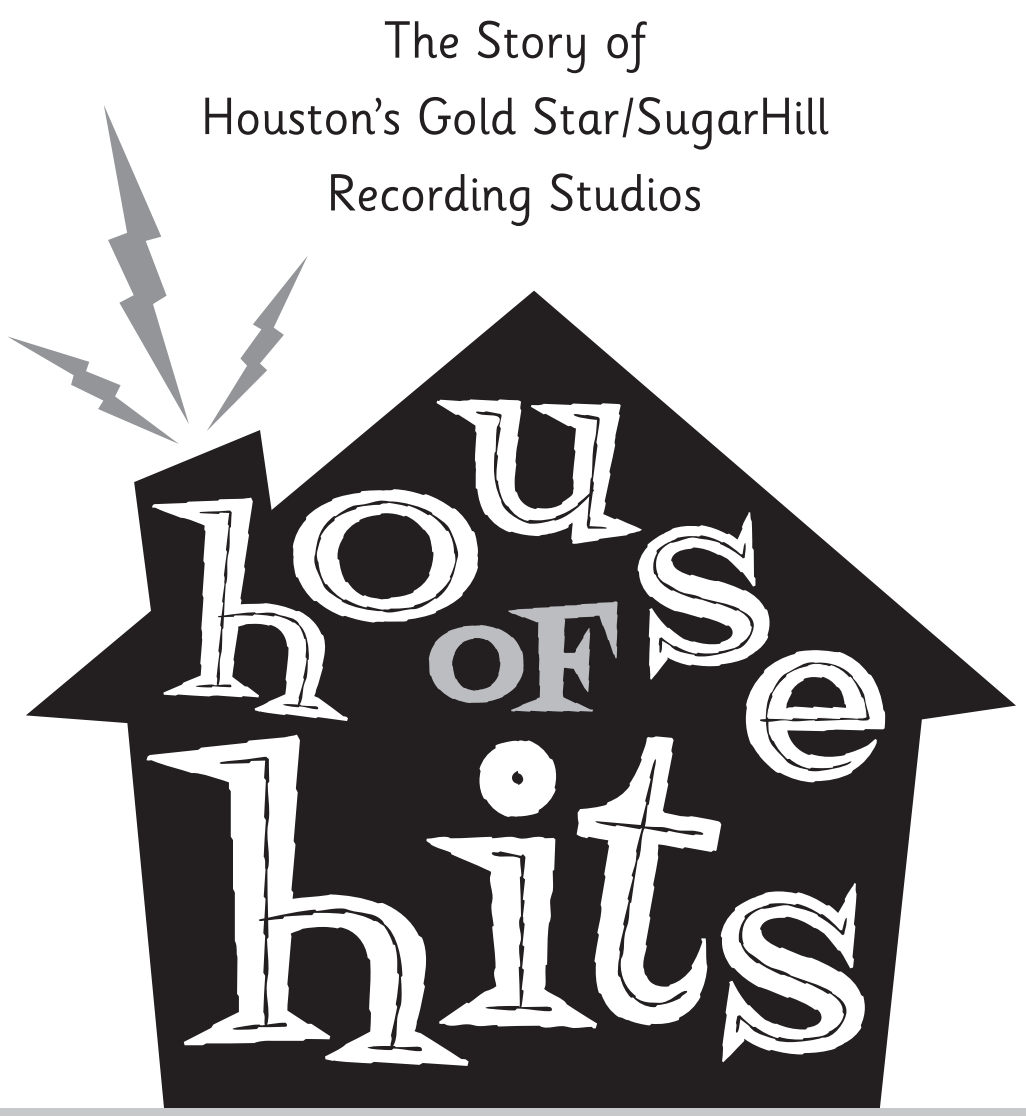

bY ANDY BRADLEY and ROGER WOOD 
Copyright (C) 2010 by the University of Texas Press

\author{
All rights reserved \\ Printed in the United States of America \\ First edition, 2010 \\ Requests for permission to reproduce material \\ from this work should be sent to: \\ Permissions: University of Texas Press \\ P.O. Box 7819, Austin, TX 78713-7819 \\ www.utexas.edu/utpress/about/bpermission.html \\ (0) The paper used in this book meets the minimum requirements \\ of ANSI/NISO Z39.48-1992 (R1997) (Permanence of Paper).
}

Designed by Lindsay Starr

Library of Congress Cataloging-in-Publication Data

Bradley, Andy, 1951-

House of hits : the story of Houston's Gold Star/SugarHill Recording

Studios / by Andy Bradley and Roger Wood. - 1st ed.

p. cm. - (Brad and Michele Moore roots music series)

Includes bibliographical references and index.

ISBN 978-0-292-71919-4 (cl. : alk. paper)

1. SugarHill Recording Studios. 2. Gold Star Studios. 3. Sound recording industry-Texas-Houston-History. I. Wood, Charles Roger, 1956- II. Title.

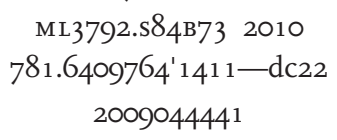

